\title{
Dose Finding Study
}

National Cancer Institute

\section{Source}

National Cancer Institute. Dose Finding Study. NCI Thesaurus. Code C158289.

An early phase clinical study with the objective of determining the optimal therapeutic dose of a drug. 